\title{
An overview of dissolved organic carbon in groundwater and implications for drinking water safety
}

\author{
S. Regan \\ Trinity College Dublin, Ireland, regans@tcd.ie \\ Paul Hynds \\ Technological University Dublin, Paul.Hynds@tudublin.ie \\ R. Flynn \\ Queen's University Belfast
}

Follow this and additional works at: https://arrow.tudublin.ie/ehsiart

Part of the Civil and Environmental Engineering Commons, and the Medicine and Health Sciences Commons

\section{Recommended Citation}

Regan, Shane \& Hynds, Paul \& Flynn, Raymond. (2017). An overview of dissolved organic carbon in groundwater and implications for drinking water safety. Hydrogeology Journal. 25. 10.1007/

s10040-017-1583-3.

This Article is brought to you for free and open access by the ESHI Publications at ARROW@TU Dublin. It has been accepted for inclusion in Articles by an authorized administrator of ARROW@TU Dublin. For more information, please contact arrow.admin@tudublin.ie, aisling.coyne@tudublin.ie,gerard.connolly@tudublin.ie.

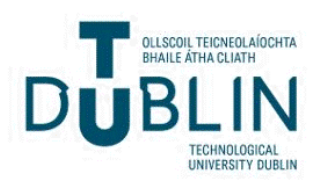


See discussions, stats, and author profiles for this publication at: https://www.researchgate.net/publication/316351764

\section{An overview of dissolved organic carbon in groundwater and implications for drinking water safety}

Article in Hydrogeology Journal · April 2017

DOI: 10.1007/510040-017-1583-3

CITATIONS

30

3 authors:

Shane Regan

National Parks and Wildlife Service

19 PUBLICATIONS 129 CITATIONS

SEE PROFILE

Raymond M Flynn

Queen's University Belfast

36 PUBLICATIONS 596 CITATIONS

SEE PROFILE
1,848

Paul D Hynds

Technological University Dublin - City Campus

115 PUBLICATIONS 722 CITATIONS

SEE PROFILE

Some of the authors of this publication are also working on these related projects:

Climate change in the Republic of Ireland: Societal health Impacts and Solutions (CRISIS) View project

Groundwater Risk app for Local Evaluation (GRAppLE) View project 


\title{
An overview of dissolved organic carbon in groundwater and implications for drinking water safety
}

\author{
S. Regan ${ }^{1} \cdot$ P. Hynds ${ }^{2} \cdot$ R. Flynn ${ }^{3}$
}

Received: 16 September 2016 / Accepted: 23 March 2017 /Published online: 22 April 2017

(C) Springer-Verlag Berlin Heidelberg 2017

\begin{abstract}
Dissolved organic carbon (DOC) is composed of a diverse array of compounds, predominantly humic substances, and is a near ubiquitous component of natural groundwater, notwithstanding climatic extremes such as arid and hyper-arid settings. Despite being a frequently measured parameter of groundwater quality, the complexity of DOC composition and reaction behaviour means that links between concentration and human health risk are difficult to quantify and few examples are reported in the literature. Measured concentrations from natural/unpolluted groundwater are typically below $4 \mathrm{mg} \mathrm{C} / \mathrm{l}$, whilst concentrations above these levels generally indicate anthropogenic influences and/or contamination issues and can potentially compromise water safety. Treatment processes are effective at reducing DOC concentrations, but refractory humic substance reaction with chlorine during the disinfection process produces suspected carcinogenic disinfectant by-products (DBPs). However, despite engineered artificial recharge systems being commonly used to remove DOC from recycled treated wastewaters, little research has been conducted on the presence of DBPs in potable groundwater systems. In recent years, the capacity to measure the influence of organic matter on colloidal contaminants and its influence on the mobility of pathogenic microorganisms has
\end{abstract}

Published in the special issue "Hydrogeology and Human Health"

S. Regan

regans@tcd.ie

1 Department of Civil, Structural and Environmental Engineering, University of Dublin Trinity College, Dublin 2, Ireland

2 Environmental Health and Sustainability Institute, Dublin Institute of Technology, Graingegorman, Dublin 7, Ireland

3 School of the Natural and Built Environment, David Keir Building, Queen's University Belfast, Stranmillis Road, Belfast BT9 5AG, UK aided understanding of transport processes in aquifers. Additionally, advances in polymerase chain reaction techniques used for the detection, identification, and quantification of waterborne pathogens, provide a method to confidently investigate the behaviour of DOC and its effect on contaminant transfer in aquifers. This paper provides a summary of DOC occurrence in groundwater bodies and associated issues capable of indirectly affecting human health.

Keywords Dissolved organic carbon $\cdot$ Health $\cdot$ Disinfectant by-products $\cdot$ Microbial processes $\cdot$ Polymerase chain reaction

\section{Introduction}

Numerous studies have examined the occurrence, source, reactivity, and transport of natural dissolved organic carbon (DOC) in aquifers (Baker et al. 2000; Chapelle et al. 2009; Longnecker and Kujawinski 2011; Shen et al. 2015); however, to date, few have focused on the indirect associations between DOC and human health. This is in part due to the diverse nature of organic compounds frequently encountered in both polluted and unpolluted groundwater, in addition to their variable levels of reactivity. While the precise composition of groundwater DOC is both temporally and spatially variable (Clay et al. 1996; Goñi and Gardner 2003; Shen et al. 2015), it typically comprises a relatively small proportion of low molecular weight compounds (i.e. carbohydrates and amino acids), and a larger proportion of more complex, high molecular weight compounds (i.e. humic substances; Artinger et al. 2000).

Organic matter of biological origin is the most frequently oxidised substance in the aqueous environment and, due to the reactive nature of a subset of biomolecular components (Aiken 2002) groundwater DOC is indicative and/or causative 
with respect to a number of subsurface microbial and geochemical processes. Some of these processes are considered beneficial, e.g. denitrification (Clay et al. 1996; Pabich et al. 2001; Thayalakumaran et al. 2008); however, DOC enrichment directly affects microbial oxygen availability and, thus, subsurface microbial survival and mobility (Aravenaa et al. 1995; Chapelle et al. 2013; Thayalakumaran et al. 2015). Moreover, high levels of dissolved organic matter (DOM) present in groundwater may decrease optical clarity (or increase turbidity), which can significantly reduce the efficacy of specific treatment processes (e.g. irradiation) and complications can arise with the formation of DOC by-products following disinfection. Similarly, the presence of high levels of DOC typically concurs with high concentrations of humic and fulvic acids (Artinger et al. 2000), potentially resulting in inhibition of molecular laboratory analyses, most notably polymerase chain reaction (PCR) and enhanced contaminant mobility; though in some polluted waters, e.g. sewage effluent, proteins and carbohydrates may dominate DOC composition (Flynn et al. 2015).

This paper provides a summary of DOC occurrence in groundwater, followed by a brief overview of some issues capable of indirectly affecting human health. Finally, a summary of where future research efforts might be focused with respect to groundwater DOC and human health is provided.

\section{Dissolved organic carbon in groundwater}

DOC represents the carbonic fraction of dissolved organic matter (DOM), typically accounting for $>90 \%$ of the total organic carbon (TOC) budget found in natural groundwaters (Batiot et al. 2003a), with particulate organic carbon (POC) accounting for the remainder. Analytically, DOC is characterised as the organic fraction capable of passing through a $0.45-\mu \mathrm{m}$ filter (Evans et al. 2005; Kolka et al. 2008). Measured DOC concentrations in groundwater have been shown to cover a wide range, from below detection limits to $>50 \mathrm{mg} / \mathrm{l}$ (Thurman 1985; Evans et al. 2005). As shown in Table 1, a DOC range of $0.1-4 \mathrm{mg} \mathrm{C} / 1$ is frequently encountered in unpolluted aquifers, however, significantly lower levels of DOC may be associated with aquifers receiving recharge where an organic horizon in a soil profile is absent (to less than detection limits, typically in the order of $0.006-0.05 \mathrm{mg} / \mathrm{l})$. Conversely, uncontaminated rivers are typically associated with DOC ranges of $1-10 \mathrm{mg} \mathrm{C/1}$ (Tao 1998), although, as might be expected, elevated concentrations are found in runoff from catchments characterised by extensive areas of organic soils, e.g. peatlands (Kolka et al. 2008). Thus, while DOC may be described as being relatively stable, in both time and space, within many groundwater environments (Pabich et al. 2001), this is not always the case, particularly where significant surface-water/groundwater interaction occurs, e.g. karst systems; accordingly, caution should be employed in its interpretation.

Low DOC concentrations frequently associated with groundwater contrast with those in pore water from overlying soil horizons, with DOC ranges of 10-200 mg C/l typically reported (Wassenaara et al. 1991; Goldscheider et al. 2006). It is in the unsaturated subsurface zone that DOC is leached from decomposing organic materials, with the principal biogeochemical processes affecting DOC removal in the vadose zone being microbial utilization, oxidation, adsorption, and metal co-precipitation (Wassenaara et al. 1991; Shen et al. 2015). These processes influence the transport of soluble organic carbon to and below the water table, in parallel with environmental, climatic and geological factors. Typically, approximately $90 \%$ of surface-derived DOC is removed prior to reaching the saturated zone (Pabich et al. 2001; Shen et al. 2015). Several studies have reported decreasing DOC concentrations in concurrence with increasing subsoil thickness and aquifer depth (Pabich et al. 2001; Goñi and Gardner 2003; Datry et al. 2004; Goldscheider et al. 2006), with DOC concentrations at or close to zero reported in deep $(>1 \mathrm{~km})$ and old groundwaters (Pabich et al. 2001). Consequently, shallow groundwater DOC characteristics are largely determined by processes operating in the soil organic horizon (Trumbore et al. 1992; Kalbitz et al. 2000), while the transfer of organic matter remaining in solution is primarily dependent on vadose zone thickness (Pabich et al. 2001; Batiot et al. 2003b; Goñi and Gardner 2003), and the level of hydraulic connectivity between subsoil horizons and the water table (Kalbitz et al. 2000).

The hydrological connectivity between the surface and subsurface is important for the transfer of DOC into shallow groundwater ecosystems, which will also be influenced by soil properties/structure and land management practice. Whilst elevated groundwater DOC (generally considered to be approximately $4 \mathrm{mg} \mathrm{C} / \mathrm{l}$ ) can occur naturally due to recharge being influenced by discharge originating from wetland environments and the presence of sedimentary organic deposits, such as coal, at depth (e.g. values of up to $200 \mathrm{mg} \mathrm{C} / 1$ reported; Artinger et al. 2000), high DOC is often associated with anthropogenic activities (Chomycia et al. 2008; Table 1). Additional organic matter from the increased use of organic fertilisers, such as manure, has been reported from dairy farm operations resulting in DOC concentrations up to $55 \mathrm{mg} \mathrm{C} / 1$ (Chomycia et al. 2008) and irrigated sugar cane fields (up to $82 \mathrm{mg} \mathrm{C} / \mathrm{l}$ ), due to organic-rich sugar mill by-products applied as fertilizer and/or sugarcane sap released during harvest (Thayalakumaran et al. 2015). DOC may also be sourced from the hyporheic zone-for example, previous studies suggest that surface water containing untreated waste has driven a rise in groundwater DOC levels up to $14 \mathrm{mg} / \mathrm{l}$ in the Bengal aquifer system of Bangladesh due to groundwater pumping from irrigated croplands during the dry season (Bhattacharya et al. 
Table 1 Selected groundwater DOC concentrations from unpolluted and polluted/enriched aquifers

\begin{tabular}{|c|c|c|c|}
\hline Author/s & $\mathrm{DOC}(\mathrm{mg} \mathrm{C} / \mathrm{l})$ & Aquifer & Impact \\
\hline \multicolumn{4}{|l|}{ Unpolluted } \\
\hline Artinger et al. 2000 & $0.3-1.5$ & Glacial sediment & - \\
\hline Artinger et al. 2000 & 0.1 to 0.5 & Sandstone bedrock & - \\
\hline Baker et al. 2000 & $1-4$ & Fluvial sediment & - \\
\hline Barcelona 1984 & 2.7 to $<4$ & Glacial sediment & - \\
\hline Batiot et al. 2003a & 1.2 & Karst bedrock & - \\
\hline Datry et al. 2004 & 0.5 & Glacial sediment & - \\
\hline Wassenaara and Aravena 1991 & $1.4-2$ & Sandstone bedrock & - \\
\hline Wassenaara et al. 1991 & 1.5 to 3.2 & Glacial sediment & - \\
\hline \multicolumn{4}{|l|}{ Polluted/enriched } \\
\hline Anawar et al. 2003 & $>1$ to $<6$ & Fluvial sediment & Sedimentary \\
\hline Aravenaa et al. 1995 & $1-18$ & Glacial sediment & Sedimentary \\
\hline Artinger et al. 2000 & $<1$ to $>200$ & Glacial sediment & Sedimentary \\
\hline Artinger et al. 2000 & $5-17$ & Fluvial sediment & Agriculture \\
\hline Barcelona 1984 & $<5$ to $>20$ & Glacial sediment & Drilling fluids \\
\hline Batiot et al. 2003b & $1-5$ & Dolomite bedrock & Irrigation water \\
\hline Bhattacharya et al. 2002 & $<1$ to $>14$ & Fluvial sediment & Sedimentary \\
\hline Chomycia et al. 2008 & $4-55$ & Fluvial sediment & Dairy farming \\
\hline Clay et al. 1996 & $<1$ to $>10$ & Glacial sediment & Agriculture \\
\hline Davis et al. 1994 & 2 to $>400$ & Fluvial sediment & Tannery leachate \\
\hline Goñi and Gardner 2003 & 6 to $>120$ & Marine sediments & Irrigation water \\
\hline Pabich et al. 2001 & $<1-23$ & Glacial sediment & Eutrophication \\
\hline Thayalakumaran et al. 2015 & $<4$ to $>80$ & Fluvial and marine sediment & Sugar-cane fields \\
\hline
\end{tabular}

Note: Sedimentary refers to naturally emplaced geological formations
2002; Harvey et al. 2002). In extreme cases, aquifers polluted by leachate from waste disposal such as a landfill, can contain DOC concentrations as high as $300 \mathrm{mg} / \mathrm{l}$ (Christensen et al. 1999). Similarly, contamination of groundwater by leachate from historical industrial activities, such as tannery facilities, has been reported as the source of significant groundwater plumes with DOC levels to as high as $400 \mathrm{mg} / \mathrm{l}$ (Davis et al. 1994).

\section{Groundwater TOC and human health}

The chemical composition of groundwater reflects the composition of water entering the subsurface, in addition to the products of kinetically controlled reactions within the aquifer matrix and overlying subsoil layers (Grützmacher et al. 2013). The composition and bioavailability of DOM are key factors affecting water quality, where observed increases in DOC concentration may be indicative of changes in water quality. For example, concentrations above background levels can provide evidence of the occurrence of groundwater contamination by organic compounds (Barcelona 1984; Harvey and Barber 1992; Longnecker and Kujawinski 2011). Whilst there are a number of issues that may be associated with TOC in groundwater and human health, such as metal mobility (Christensen et al. 1999), the following sections provide an overview of three rarely examined issues with regard to groundwater DOC measurements and their interpretation within the context of human health.

\section{Groundwater DOM, treatment approaches and efficacy}

High levels of DOM in water are known to cause aesthetic and odour problems, while possibly promoting the growth and proliferation of pathogenic bacteria (Pernthaler 2005; Goldscheider et al. 2006; Gopal et al. 2007). Unpolluted groundwater generally lacks any discernible colour and is therefore considered optically clear (Chapelle et al. 2016), though not necessarily in dynamic groundwater/surfacewater systems such as karst. However wastewater ingress to groundwater recharge, due to an absence of natural subsurface attenuation and/or localised preferential pathways (e.g. poorly located or malfunctioning septic tanks), can increase groundwater DOC concentrations and thus cause (dis)coloration via elevated levels of humic materials (Westerhoff and Pinney 2000; Rittmann et al. 2002). The solubilization of heavy metals by complexation with humic substances is known to be of considerable importance in coloured natural waters 
(Oliver et al. 1983). Also, the persistence of high DOC loading has significant implications for the fate of other contaminants such as pesticides, pathogens, and pharmaceuticals, as hypoxic conditions may restrict the degradation of many carbonbased compounds (Chomycia et al. 2008), though in some instances it may promote it.

There are numerous water treatment technologies applied for DOC reduction such as flocculation and filtration engineering techniques. Advanced treatment typically employs ozonation, which cleaves the unsaturated bonds in the aromatic molecular components of humic materials, thereby decreasing colour, in addition to increasing the degradability of organic molecules (Rittmann et al. 2002). While ozonation has been shown to reduce DOC, the magnitude of reduction is limited $(<10 \%)$; accordingly, additional treatment processes, typically engineered biofiltration approaches, are required to provide further DOM reductions (Drewes and Jekel 1998). However, when wastewater is to be released to groundwater, further treatment can be achieved by soil aquifer treatment (SAT), which utilises the attenuation properties of the subsoil zone and concurrently recycles wastewater while augmenting recharge (Drewes and Jekel 1998). SAT systems are typically employed in areas characterised by limited conventional freshwater resources and overexploited local aquifers, e.g. arid regions (Kim and Yu 2007), developing countries (Westerhoff and Pinney 2000), and heavily urbanised environments (Drewes and Jekel 1998).

Drinking-water treatment facilities, including the pretreatment of SAT recharge, typically involves disinfection via chlorination in order to ensure satisfactory potable water supplies and to prevent microbial growth during distribution (Chomycia et al. 2008; Uyak et al. 2008); however, this approach may be problematic as chlorine may react with DOC to produce potentially harmful disinfection by-products (DBPs) including trihalomethanes (THMs) and haloacetic acids (HAAs), both of which are suspected carcinogens (WHO 2011). The concentrations of both are currently regulated across the European Union by Council Directive 98/83/EC and in the United States by the US Environmental Protection Agency (Safe Water Drinking Act). The total concentration of DBPs present and the distribution of individual compounds in chlorinated water depend upon the initial raw water characteristics, in addition to operational parameters during the treatment process such as pH and temperature (Kim and Yu 2007; Uyak et al. 2008). The complex polymeric properties of humic substances result in significant difficulties with respect to effective environmental characterisation. Previous studies have shown that humic substances are imperative precursors to the development of DBPs and strongly influence the formation potential of THMs, much more so than the non-humic faction of organic matter (Westerhoff and Pinney 2000; Kim and Yu 2007).

Investigations of DOC treatment processes consistently confirm that biodegradation of DOC represents the dominant removal mechanism during treatment, with preferential removal of low molecular weight DOC (Drewes and Jekel 1998; Westerhoff and Pinney 2000; Kim and Yu 2007). DOC removal typically exhibits moderate $(50 \%)$ to high (90\%) removal efficiencies (Quanrud et al. 2003a). However, the bias towards refractory humic substance components remaining in DOC solution complicates treatment efficacy as DBP precursors with THM formation potential (THMFP) are persistent factions of DOC and whose reactivity may increase post-treatment due to removal on non-reactive species (Westerhoff and Pinney 2000; Quanrud et al. 2003b). Nevertheless, whilst associations have been found between increased instance of specific cancers (e.g. rectal, kidney) and consumption of chlorinated drinking water (Kuo et al. 2010; Liao et al. 2012), few studies have been carried out on demonstrated cancer occurrences as a result of THM/DBP presence in potable groundwater supplies. Subsequently, despite engineered artificial recharge systems being commonly used to remove DOC from recycled treated wastewaters, little research has been conducted on the presence of DBPs in groundwater systems receiving artificial recharge.

\section{Organic matter and colloidal mobility}

"Colloidal contaminants" include some of the earliest known pollutants recognised to impact water quality such as pathogenic microorganisms (bacteria, viruses and protozoa; Macler and Merkle 2000). More recent investigations have recognised that natural colloidal materials can facilitate the transport of low solubility substances (Kretzschmar et al. 1999), while, by products of recent technological developments, including engineered nanoparticles (Nuttall and Kale 1994), represent emerging contaminants of concern that may also impact human health (Troester et al. 2016). As frequently alluded to throughout the current Hydrogeology Journal special issue Hydrogeology and Human Health, the importance of aquifers as drinking water sources in many parts of the world cannot be overstated, and thus, an increase in understanding of colloid mobility in the subsurface will likely prove fundamental to the development of successful source protection strategies (Flynn et al. 2015; Hunt and Johnson 2016) as, in contrast to solutes, pathogens can cause infection at exceedingly low levels of exposure and are often associated with rapid (<10 year) subsurface flow (Hunt and Johnson 2016).

In spite of considerable recent advances made in understanding fundamental processes responsible for attenuation under controlled (laboratory) conditions, factors influencing colloidal fate and transport in natural porous media remain poorly defined. Complicating factors include the higher degrees of compositional and textural heterogeneity encountered in natural deposits (Flynn et al. 2015), in addition to other factors such as the co-occurrence of suites with other contaminants that may promote or inhibit colloid mobility. 
At present, the conceptual understanding of colloid mobility largely relies on approaches developed for engineered filter beds, where removal capacity has been shown to depend on the chemical and physical properties of the contaminants, collector surfaces (i.e. grains and fissure walls), and the inorganic hydrochemistry of the host solution, most notably ionic strength and pH (Kretzschmar et al. 1999). The role of DOC adds another layer of complexity to effective characterisation.

Despite its widespread occurrence in natural waters and the frequently observed relationship between DOC and colloids in certain polluted settings, e.g. sewage impacted groundwater (Flynn et al. 2012), colloid-organic matter interactions have received relatively little research attention until recently (Bradbury et al. 2013; Yang et al. 2015). Qualitative observations have indicated that diverse mechanisms may operate, ranging from promotion to inhibition of mobility (Kretzschmar et al. 1999). The contrasting responses are perhaps unsurprising, given the range of organic compounds present in the wider environment in both natural and polluted settings (Harvey et al. 2010a, 2010b).

The capacity of organic matter $(\mathrm{OM})$ to stabilise colloids in suspension has been recognised for some time (Kretzschmar et al. 1997), while more recent studies have begun to shed light on the capacity of OM to influence the attenuation capacity in saturated porous media-for example, Yang et al. (2010) carried out multiple pulse dynamic column studies at laboratory scale, coupled with random sequential adsorption modelling (RSA) of tracer breakthrough curves to quantify the influence of OM on colloid mobility. This approach provided a basis for further investigations to highlight the complexity of OM-colloidal contaminant interactions in the subsurface environment. Using RSA modelling, Yang et al. (2011) employed engineered particles (fluorescent microspheres) to show how changes in ionic strength and $\mathrm{pH}$, with comparable compositions to those observed in natural waters, dramatically altered the capacity of a well characterised humic acid to influence the colloid attenuation capacity of a saturated sand; such changes may contribute to increases in colloid contamination in groundwaters following recharge events, as noted by Hunt and Johnson (2016).

Subsequent studies further highlighted the complexity of colloid-OM interactions. Flynn et al. (2012) employed a wellcharacterised protein (Bovine Serum Albumin) in place of humic acid, to reveal comparable blocking responses at low concentrations, whereas application of higher concentrations generated breakthrough curves reflecting "ripening" behaviour. Furthermore, Yang et al. (2012) have identified additional processes of potential hydrogeological significance, including the capacity of compounds to dissolve favourable deposition sites, such as iron oxide patches on grain surfaces, thus promoting greater colloid mobility.

Despite progress in characterising colloid-OM interactions in the laboratory, DOC's influence on colloid migration in groundwater systems remains largely uncharacterised. Nonetheless, realistic conceptual models provide a reliable basis for upscaling and identification of potentially relevant settings - for example, while the impacts of changes in water chemistry on colloid mobility are expected to be of greater significance in surface water systems, similar changes can also be anticipated in karst, where field experimentation, albeit in the absence of organic matter, has demonstrated the capacity of hydrochemical changes to effectively mobilise particles deposited under conditions more conducive to detachment (Flynn and Sinreich 2010). Similarly, as studies employing DOC have demonstrated, contrasts in concentration, which occur between the margins of a contaminant plume and its centre may give rise to contrasting colloid attenuation capacity (Harvey et al. 2011). This information, coupled with the findings of Flynn et al. (2012) suggests that some DOC may be capable of promoting or inhibiting colloid mobility at different stages of a plume's development. Furthermore, alterations to the content/configuration of deposited $\mathrm{OM}$, arising from processes including OM degradation and/or changes in hydrochemistry, may give rise to temporal changes in the capacity of aquifers to disinfect groundwater.

From the aforementioned, it is clear that characterising the influence of DOC on colloidal contaminant occurrence in aquifers is a complex topic; moreover, effective characterisation of colloid-OM interactions at the field scale continues to present a significant challenge, largely due to inherently lower levels of experimental control. Nevertheless, it is widely acknowledged that findings from laboratory-based investigations require complementary in-situ testing in order to accurately assess the relative importance of a potentially vast range of mechanisms in which OM may influence colloid fate and transport. Field-based artificial tracer testing, when employed within a realistic hydrogeological framework, which considers findings of studies completed under more controlled (laboratory) conditions, represents a useful approach to better understanding these processes (Flynn et al. 2015). Findings from limited studies completed to date (e.g. Harvey et al. 2011; Metge et al. 2010; Pieper et al. 1997) suggest that this will prove a fruitful area of research for future investigations, ultimately leading to more scientifically defensible groundwater protection strategies.

\section{Inhibition of polymerase chain reaction (PCR)}

Those who drink groundwater that has not been disinfected are at increased risk of infection and disease from pathogenic microorganisms (Macler and Merkle 2000; Borchardt et al. 2012; Hynds et al. 2014a). Polymerase chain reaction (PCR) is increasingly being employed as the standard method for detection and characterization of (pathogenic and nonpathogenic) microorganisms and genetic markers in a variety of water types including groundwater (Schrader et al. 2012). A 
recent systematic review of groundwater contamination in the United States and Canada found that almost three quarters of relevant studies from 1990 to 2013 employed PCR as the principal pathogen detection method (Hynds et al. 2014b). The method employs a process whereby nucleic acid sequences (i.e. microbial "building blocks") are enzymatically amplified from non-detectable to detectable levels (Kong et al. 2002; De Man et al. 2014). During the process, strands of the DNA double helix, initially present in very small numbers, are physically separated via DNA thermal melting, followed by highly selective amplification by DNA polymerase. Amplification usually takes place over 35-45 cycles, resulting in exponential multiplication of the number of DNA fragments of interest originally present (Girones et al. 2010; Ramírez-Castillo et al. 2015). Since its development in the early 1980s, PCR has become a rapid, highly specific, low cost method for microbial detection, and is now regularly used in the field of environmental science (Abbaszadegan et al. 1999; Schrader et al. 2012). Moreover, due to increasing accuracy, in parallel with decreasing costs, these techniques are now frequently employed for quantitative risk assessment and regulation of both drinking and recreational waters (Gibson et al. 2012).

Despite the multiple advantages associated with PCR, the process is prone to inhibition by naturally occurring substances (inhibitors) in groundwater; PCR inhibitors represent a diverse group of organic and inorganic chemicals including urea, phenol, ethanol, complex polysaccharides, bacterial debris, metal ions, humic acids, and tannic acid, among others (Radstrom et al. 2004; Schrader et al. 2012). The presence of varying concentrations of inhibitory compounds in water samples will disrupt amplification of target nucleic acids via a number of biochemical processes (Shain and Clemens 2008; Radstrom et al. 2008). This results in partial or total PCR inhibition, leading to decreased sensitivity or false-negative results, respectively. Accordingly, this potential underestimation represents the primary source of concern with respect to identifying poor water quality using PCR methodology.

As previously outlined, humic acids and other humic substances are typically present in groundwater with high levels of dissolved organic carbon, (Artinger et al. 2000; Rock et al. 2010). This in turn will interact with template DNA and the polymerase, even at low concentrations, thus preventing the enzymatic reaction (Sutlovic et al. 2008). It is important to note that levels of inhibition will primarily depend on the relative concentration of the inhibitor and not its source. A recent PCR inhibition study undertaken by Gibson et al. (2012) comprised 2187 groundwater samples taken from domestic and municipal boreholes associated with relatively deep sandstone aquifers in Wisconsin. Overall, $4 \%$ of groundwater samples were associated with false-negative results for viral pathogens due to the effects of inhibitory compounds, with inhibitory concentrations in groundwater samples found to span four orders of magnitude (Gibson et al. 2012). Results suggest that numerous factors including sample volume, site location and seasonality affected inhibition levels; it was not possible to spatially assess or predict inhibition potential, and thus it is recommended that all groundwater samples be analysed for inhibition prior to PCR, and particularly when sampling is associated with a human health event and/or (expected) high groundwater DOC concentrations, i.e. groundwater from karstic areas and peatlands (Borchardt et al. 2003; Kolka et al. 2008; Gibson et al. 2012).

\section{Summary}

The current paper presents an overview of the occurrence of dissolved organic carbon (DOC) in groundwater, and its implications for human health linked to interactions with other substances. Treatment processes for DOM effectively reduce DOC concentrations; however, humic substances are difficult to remove from solution and react with chlorine in the disinfection process to produce DBPs, most notably THMs, many of which are suspected carcinogens. Whilst connections between human cancer occurrences and ingestion have been made for treated surface-water supplies, there are no such studies from supplies using publicly supplied groundwater. Considering many domestic and public drinking water wells are often located in close proximity to arable and agricultural activities that require treatment, this may be a significant and persistent, yet poorly understood, health risk, both in developing and developed countries. Moreover, the use of reclaimed and treated wastewater for engineered aquifer recharge is an increasingly common practice in many regions of the world, which indicates that aquifers utilised by human populations, both in urban and rural areas, may already have undesirable DBP concentrations.

Until recently, relatively little attention had been given to mechanisms behind the interactions between OM and colloidal contaminants, and their influence on the mobility of pathogenic microorganisms in the subsurface. The capacity to quantify these processes now provides a means to more confidently investigate the behaviour of $\mathrm{OM}$ in saturated porous media and for colloidal contaminant transport in aquifers. Further development of this topic, necessary to protect groundwater supplies, will require investigations spanning a range of investigative scales and disciplines. Although there remains a need for further laboratory-based investigations to identify fundamental processes, a need for further field-scale investigations is outstanding if the importance of these processes in natural systems is to be defined. The role of the hydrogeologist is anticipated to prove fundamental in bridging this divide. 
PCR techniques are now frequently used for the detection, identification, and quantification of waterborne pathogens-for example, Sezen et al. (2014) recently reported on a large waterborne multi-pathogen gastroenteritis outbreak in Turkey, which was found to be caused by consumption of contaminated groundwater from historic neighbourhood fountains. This investigation comprised the use of real-time multiplex PCR, with results proving the source of the outbreak, in addition to the causative pathogens (Shigella sonnei, astrovirus, and norovirus). Accordingly, the study authors were able to provide fast, reliable evidence-based recommendations pertaining to both avoidance of new cases and treatment of existing cases, thereby significantly contributing to public health in the affected region. However, PCR inhibition by humic substances is capable of resulting in significant underestimation or false-positives (Abbaszadegan et al. 1999; Radstrom et al. 2008; Schrader et al. 2012), thus potentially resulting in a failure to correctly detect the source of an ongoing human health event associated with groundwater supplies. While groundwater derived from specific settings may be expected to comprise high levels of PCR inhibitors due to high groundwater DOC concentrations, i.e. karstic areas and peatlands (Borchardt et al. 2003; Kolka et al. 2008), and should therefore be systematically analysed for inhibition prior to the use of PCR, a recent study by Gibson et al. (2012) found that $4 \%$ of groundwater samples from deep non-karstic aquifers in the US $(n=2187)$ produced false-negative results. Moreover, results from the same study showed that sample volume, site location and seasonality affected inhibition levels; thus, it is recommended that, in the short-term, all groundwater samples be systematically analysed for levels of inhibition due to the presence of humic acids prior to PCR, and in the medium- to long-term, regionally or hydrogeologically specific studies seek to quantify temporal variation associated with PCR inhibitors in groundwater, particularly in vulnerable areas, and those associated with previous waterborne outbreaks.

This paper has identified three key issues associated with DOC in groundwater, namely the presence of DBPs, colloidal transport mechanisms and usage of PCR techniques, in treated and/or untreated groundwater used in municipal water supply. Future research efforts on these issues should be directed with respect to groundwater DOC and human health, as currently, these issues are under-represented in published literature. Other issues of concern not covered here include optical clarity and the presence of chromophoric dissolved organic matter, which effects ultraviolet/visible light absorbance, and this also warrants increased investigation in coloured municipal groundwater supplies, as a means to better understand the factors and processes leading to DOC enrichment.

\section{References}

Abbaszadegan M, Stewart P et al (1999) A strategy for detection of viruses in groundwater by PCR. Applied Environ Microbiol 65(2): 444-449

Aiken G (2002) Organic matter in ground water. US Geological Survey Artificial Recharge Workshop Proceedings, Sacramento, CA, 2-4 April 2002

Anawar H, Akai J et al (2003) Geochemical occurrence of arsenic in groundwater of Bangladesh: sources and mobilization processes. $\mathrm{J}$ Geochem Explor 77(2):109-131

Aravenaa R, Wassenaar LI et al (1995) Distribution and isotopic characterization of methane in a confined aquifer in southern Ontario, Canada. J Hydrol 173(1):51-70

Artinger R, Buckau G et al (2000) Characterization of groundwater humic substances: influence of sedimentary organic carbon. Applied Geochem 15(1):97-116

Baker M, Valett $\mathrm{H}$ et al (2000) Organic carbon supply and metabolism in a shallow groundwater ecosystem. Ecology 81(11):3133-3148

Barcelona MJ (1984) TOC determinations in ground water. Ground Water 22(1):18-24

Batiot C, Emblanch C et al (2003a) Total organic carbon (TOC) and magnesium $(\mathrm{Mg} 2+)$ : two complementary tracers of residence time in karstic systems. CR Geosci 335(2):205-214

Batiot C, Liñán C et al (2003b) Use of total organic carbon (TOC) as tracer of diffuse infiltration in a dolomitic karstic system: the Nerja Cave (Andalusia, southern Spain). Geophys Res Lett 30(22). 10. 1029/2003GL018546

Bhattacharya P, Jacks G et al (2002) Arsenic in groundwater of the Bengal Delta Plain aquifers in Bangladesh. Bull Environ Contamin Toxicol 69(4):538-545

Borchardt MA, Bertz PD et al (2003) Incidence of enteric viruses in groundwater from household wells in Wisconsin. Applied Environ Microbiol 69(2):1172-1180

Borchardt MA, Spencer SK et al (2012) Viruses in nondisinfected drinking water from municipal wells and community incidence of acute gastrointestinal illness. Environ Health Perspect 120(9):1272

Bradbury KR, Borchardt MA et al (2013) Source and transport of human enteric viruses in deep municipal water supply wells. Environ Sci Technol 47(9):4096-4103

Chapelle FH, Bradley PM et al (2009) Biochemical indicators for the bioavailability of organic carbon in ground water. Ground Water 47(1):108-121

Chapelle FH, Bradley PM et al (2013) Assessing the relative bioavailability of DOC in regional groundwater systems. Groundwater 51(3):363-372

Chapelle FH, ShenY et al (2016) The removal kinetics of dissolved organic matter and the optical clarity of groundwater. Hydrogeol $\mathrm{J}$ 24(6):1413-1422

Chomycia JC, Hernes PJ et al (2008) Land management impacts on dairy-derived dissolved organic carbon in ground water. J Environ Quality 37(2):333-343

Christensen JB, Botma JJ et al (1999) Complexation of $\mathrm{Cu}$ and $\mathrm{Pb}$ by DOC in polluted groundwater: a comparison of experimental data and predictions by computer speciation models (WHAM and MINTEQA2). Water Res 33(15):3231-3238

Clay D, Clay S et al (1996) Temporal variability of organic C and nitrate in a shallow aquifer. Water Res 30(3):559-568

Datry T, Malard F et al (2004) Dynamics of solutes and dissolved oxygen in shallow urban groundwater below a stormwater infiltration basin. Sci Total Environ 329(1-3):215-229

Davis A, Kempton JH et al (1994) Groundwater transport of arsenic and chromium at a historical tannery, Woburn, Massachusetts, USA. Applied Geochem 9(5):569-582 
De Man H, Van Den Berg H et al (2014) Quantitative assessment of infection risk from exposure to waterborne pathogens in urban floodwater. Water Res 48:90-99

Drewes JE, Jekel M (1998) Behavior of DOC and AOX using advanced treated wastewater for groundwater recharge. Water Res 32(10): 3125-3133

Evans C, Monteith D et al (2005) Long-term increases in surface water dissolved organic carbon: observations, possible causes and environmental impacts. Environ Pollut 137(1):55-71

Flynn RM, Sinreich M (2010) Characterisation of virus transport and attenuation in epikarst using short pulse and prolonged injection multi-tracer testing. Water Res 44(4):1138-1149

Flynn RM, Yang X et al (2012) Bovine serum albumin adsorption to ironoxide coated sands can change microsphere deposition mechanisms. Environ Sci Technol 46(5):2583-2591

Flynn RM, Mallan G et al (2015) Characterizing aquifer heterogeneity using bacterial and bacteriophage tracers. J Environ Quality 44(5): $1448-1458$

Gibson KE, Schwab KJ et al (2012) Measuring and mitigating inhibition during quantitative real time PCR analysis of viral nucleic acid extracts from large-volume environmental water samples. Water Res 46(13):4281-4291

Girones R, Ferrus M et al (2010) Molecular detection of pathogens in water-the pros and cons of molecular techniques. Water Res 44(15): 4325-4339

Goldscheider N, Hunkeler D et al (2006) Review: microbial biocenoses in pristine aquifers and an assessment of investigative methods. Hydrogeol J 14(6):926-941

Goñi MA, Gardner IR (2003) Seasonal dynamics in dissolved organic carbon concentrations in a coastal water-table aquifer at the forestmarsh interface. Aquatic Geochem 9(3):209-232

Gopal K, Tripathy SS et al (2007) Chlorination byproducts, their toxicodynamics and removal from drinking water. J Hazard Mater 140(1-2):1-6

Grützmacher G, Kumar PJS et al (2013) Geogenic groundwater contamination: definition, occurrence and relevance for drinking water production. Zbl Geol Paläont Teil I 1:69-75

Harvey CF, Swartz CH et al (2002) Arsenic mobility and groundwater extraction in Bangladesh. Science 298(5598):1602-1606

Harvey RW, Barber LB (1992) Associations of free-living bacteria and dissolved organic compounds in a plume of contaminated groundwater. J Contam Hydrol 9(1-2):91-103

Harvey RW, Metge DW et al (2010a) Effects of altered groundwater chemistry upon the $\mathrm{pH}$-dependency and magnitude of bacterial attachment during transport within an organically contaminated sandy aquifer. Water Res 44(4):1062-1071

Harvey RW, Metge DW et al (2010b) Effects of altered groundwater chemistry upon the $\mathrm{pH}$-dependency and magnitude of bacterial attachment during transport within an organically contaminated sandy aquifer. Water Res 44(4):1062-1071

Harvey RW, Metge DW et al (2011) Differential effects of dissolved organic carbon upon re-entrainment and surface properties of groundwater bacteria and bacteria-sized microspheres during transport through a contaminated, sandy aquifer. Environ Sci Technol 45(8):3252-3259

Hunt RJ, Johnson WP (2016) Pathogen transport in groundwater systems: contrasts with traditional solute transport. Hydrogeol J doi:10.1007/ s10040-016-1502-Z

Hynds PD, Misstear BD, Gill LW (2014a) A quantitative risk assessment of vero-toxin producing E. coli (VTEC) in drinking water from unregulated groundwater sources in the Republic of Ireland. Hum Ecol Risk Assess J 20(6):1446-1468

Hynds PD, Thomas MK et al (2014b) Contamination of groundwater systems in the US and Canada by Enteric Pathogens, 1990-2013: a review and pooled-analysis. PloS one 9(5):e93301
Kalbitz K, Solinger S et al (2000) Controls on the dynamics of dissolved organic matter in soils: a review. Soil Sci 165(4):277-304

Kim H-C, Yu M-J (2007) Characterization of aquatic humic substances to DBPs formation in advanced treatment processes for conventionally treated water. J Hazard Mater 143(1-2):486-493

Kolka R, Weishampel P et al (2008) Measurement and importance of dissolved organic carbon. In: Hoover CM (ed) Field measurements for forest carbon monitoring: a landscape-scale approach. Springer, Dordrecht, The Netherlands, pp 171-176

Kong F, Gowan S et al (2002) Serotype identification of group B streptococci by PCR and sequencing. J Clin Microbiol 40(1):216-226

Kretzschmar R, Sticher H et al (1997) Effects of adsorbed humic acid on surface charge and flocculation of kaolinite. Soil Sci Am J 61(1): 101-108

Kretzschmar R, Borkovec M et al (1999) Mobile subsurface colloids and their role in contaminant transport. Adv Agron 66:121-193

Kuo H-W, Chen P-S et al (2010) Trihalomethanes in drinking water and the risk of death from rectal cancer: does hardness in drinking water matter? J Toxicol Environ Health A 73(12):807-818

Liao Y-H, Chen C-C et al (2012) Trihalomethanes in drinking water and the risk of death from kidney cancer: does hardness in drinking water matter? J Toxicol Environ Health A 75(6):340-350

Longnecker K, Kujawinski EB (2011) Composition of dissolved organic matter in groundwater. Geochim Cosmochim Acta 75(10):27522761

Macler AB, Merkle CJ (2000) Current knowledge on groundwater microbial pathogens and their control. Hydrogeol J 8(1):29-40

Metge DW, Harvey RW et al (2010) Influence of organic carbon loading, sediment associated metal oxide content and sediment grain size distributions upon Cryptosporidium parvum removal during riverbank filtration operations, Sonoma County, CA. Water Res 44(4): 1126-1137

Nuttall HE, Kale R (1994) Remediation of toxic particles from groundwater. J Hazard Mater 37(1):41-48

Oliver BG, Thurman EM et al (1983) The contribution of humic substances to the acidity of colored natural waters. Geochim Cosmochim Acta 47(11):2031-2035

Pabich WJ, Valiela I et al (2001) Relationship between DOC concentration and vadose zone thickness and depth below water table in groundwater of Cape Cod, USA. Biogeochemistry 55(3):247-268

Pernthaler J (2005) Predation on prokaryotes in the water column and its ecological implications. Nature Rev Microbiol 3(7):537-546

Pieper AP, Ryan JN et al (1997) Transport and recovery of bacteriophage PRD1 in a sand and gravel aquifer: effect of sewage-derived organic matter. Environ Sci Technol 31(4):1163-1170

Quanrud DM, Arnold RG et al (2003a) Fate of effluent organic matter during soil aquifer treatment: biodegradability, chlorine reactivity and genotoxicity. J Water Health 1(1):33-44

Quanrud DM, Hafer J et al (2003b) Fate of organics during soil-aquifer treatment: sustainability of removals in the field. Water Res 37(14): 3401-3411

Radstrom P, Knutsson R et al (2004) Pre-PCR processing. Molecular Biotechnol 26(2):133-146

Radstrom P, Lofstrom C et al (2008) Strategies for overcoming PCR inhibition. In: PCR primer, Cold Spring Harbor, New York. doi: 10.1101/pdb.top20

Ramírez-Castillo FY, Loera-Muro A et al (2015) Waterborne pathogens: detection methods and challenges. Pathogens 4(2):307-334

Rittmann BE, Stilwell D et al (2002) Treatment of a colored groundwater by ozone-biofiltration: pilot studies and modeling interpretation. Water Res 36(13):3387-3397

Rock C, Alum A et al (2010) PCR inhibitor levels in concentrates of biosolid samples predicted by a new method based on excitationemission matrix spectroscopy. Applied Environ Microbiol 76(24): 8102-8109 
Schrader C, Schielke A et al (2012) PCR inhibitors: occurrence, properties and removal. J Applied Microbiol 113(5):1014-1026

Sezen F, Aval E et al (2014) A large multi-pathogen gastroenteritis outbreak caused by drinking contaminated water from antique neighbourhood fountains, Erzurum city, Turkey, December 2012. Epidemiol Infect 143(04):704-710

Shain EB, Clemens JM (2008) A new method for robust quantitative and qualitative analysis of real-time PCR. Nucleic Acids Res 36(14): e91-e91

Shen Y, Chapelle FH et al (2015) Origins and bioavailability of dissolved organic matter in groundwater. Biogeochemistry 122(1):61-78

Sutlovic D, Gamulin S et al (2008) Interaction of humic acids with human DNA: proposed mechanisms and kinetics. Electrophoresis 29(7): $1467-1472$

Tao S (1998) Spatial and temporal variation in DOC in the Yichun River, China. Water Res 32(7):2205-2210

Thayalakumaran T, Bristow KL et al (2008) Geochemical conditions in groundwater systems: implications for the attenuation of agricultural nitrate. Agric Water Manage 95(2):103-115

Thayalakumaran T, Lenahan MJ et al (2015) Dissolved organic carbon in groundwater overlain by irrigated sugarcane. Groundwater 53(4): 525-530

Thurman EM (1985) Humic substances in groundwater. In: Aiken GR, McKnight DM, Wershaw RL, MacCarthy P (eds) Humic Substances in Soil, Sediment and Water. Wiley, New York, pp 87-103

Troester M, Brauch H-J et al (2016) Vulnerability of drinking water supplies to engineered nanoparticles. Water Res 96:255-279

Trumbore SE, Schiff SL et al (1992) Sources and transformation of dissolved organic carbon in the Harp Lake forested catchment: the role of soils. Radiocarbon 34(3):626-635
Uyak V, Ozdemir K et al (2008) Seasonal variations of disinfection byproduct precursors profile and their removal through surface water treatment plants. Sci Total Environ 390(2):417-424

Wassenaara L, Aravena R et al (1991) Radiocarbon in dissolved organic carbon, a possible groundwater dating method: case studies from Western Canada. Water Resour Res 27(8):1975-1986

Wassenaara LI, Aravena R et al (1991) Controls on the transport and carbon isotopic composition of dissolved organic carbon in a shallow groundwater system, central Ontario, Canada. Chem Geol 87(1):39-57

Westerhoff P, Pinney M (2000) Dissolved organic carbon transformations during laboratory-scale groundwater recharge using lagoon-treated wastewater. Waste Manage 20(1):75-83

WHO (2011) Guidelines for drinking-water quality. World Health Organization, Geneva, pp 303-304

Yang X, Flynn R et al (2010) Quantifying the influence of humic acid adsorption on colloidal microsphere deposition onto iron-oxidecoated sand. Environ Pollut 158(12):3498-3506

Yang X, Flynn R et al (2011) Influence of ionic strength and $\mathrm{pH}$ on the limitation of latex microsphere deposition sites on iron-oxide coated sand by humic acid. Environ Pollut 159(7):1896-1904

Yang X, Liang D et al (2012) Quantifying the influence of EDTA on polymer nanoparticle deposition and retention in an iron-oxidecoated sand column. J Environ Monitor 14(9):2392-2398

Yang X, Zhang Y et al (2015) Interplay of natural organic matter with flow rate and particle size on colloid transport: experimentation, visualization, and modeling. Environ Sci Technol 49(22):1338513393 